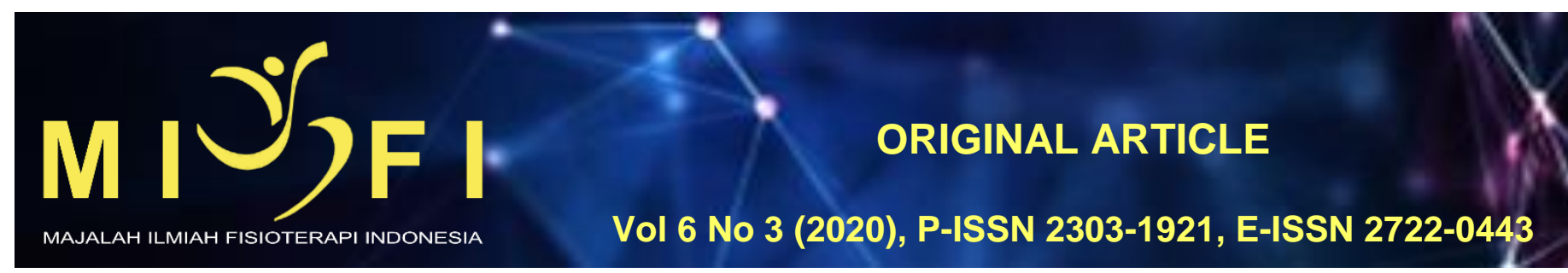

\title{
HUBUNGAN PERSENTASE LEMAK TUBUH DAN IMT DENGAN KEKUATAN OTOT GENGGAM PADA REMAJA PUTRI USIA 15-17 TAHUN DI SMK KESEHATAN BALI MEDIKA DENPASAR
}

\author{
I Gusti Agung Ayu Narita Savitri', I Made Niko Winaya ${ }^{2}$, I Made Muliarta ${ }^{3}$, I Putu Adiartha Griadhi ${ }^{3}$ \\ ${ }_{1}^{1}$ Program Studi Sarjana Fisioterapi dan Profesi Fisioterapi, Fakultas Kedokteran Universitas Udayana, Denpasar, Bali \\ ${ }^{2}$ Departemen Fisioterapi, Fakultas Kedokteran Universitas Udayana, Denpasar, Bali \\ ${ }^{3}$ Departemen IImu Faal, Fakultas Kedokteran Universitas Udayana, Denpasar, Bali \\ naritasavitri14@gmail.com
}

\begin{abstract}
ABSTRAK
Kekuatan otot genggam adalah salah satu elemen penting dalam melakukan aktivitas. Tujuan penelitian ini adalah untuk mengetahui hubungan antara persentase lemak tubuh dan IMT dengan kekuatan otot genggam pada remaja putri usia 15-17 tahun di SMK Kesehatan Bali Medika Denpasar. Penelitian ini merupakan penelitian cross sectional analytic yang dilakukan pada April 2019. Sample diambil dengan teknik Simple Random Sampling dengan sampel berjumlah 85 orang. Uji hipotesis yang digunakan adalah Chi Square Test dan didapatkan hasil nilai p 0,002 untuk hubungan kekuatan otot genggam dengan persentase lemak tubuh, dan p 0,024 untuk hubungan dengan IMT, atau $\mathrm{p}<0,05$. Prevalence Ratio remaja memiliki kekuatan otot genggam kategori lemah adalah 4,073 [95\% Cl 1,629$10,186]$ untuk kategori persentase lemak overweight dan obesitas dibandingkan kategori good dan acceptable serta 2,771 [95\% Cl 1,128-6,808] untuk perbandingan kategori IMT obesitas dan gemuk dengan kategori normal. Berdasarkan hasil penelitian maka dapat disimpulkan terdapat hubungan antara persentase lemak tubuh dengan kekuatan otot genggam, dan hubungan antara IMT dengan kekuatan otot genggam pada remaja putri usia 15-17 tahun di SMK Kesehatan Bali Medika Denpasar. Kategori overweight dan obesitas memiliki risiko 4,073 kali lebih tinggi berkategori otot genggam lemah dibandingkan kategori persentase lemak good dan acceptable, dan kategori IMT gemuk dan obesitas memiliki risiko berkategori kekuatan otot genggam lemah 2,771 kali lebih tinggi dibandingkan dengan seseorang berkategori IMT normal.
\end{abstract}

Kata Kunci : persentase lemak tubuh, IMT, kekuatan otot genggam

\section{THE CORRELATION BETWEEN BODY FAT PERCENTAGE AND BMI WITH HAND GRIP STRENGTH OF TEENAGE GIRL AGED 15-17 YEARS OLD AT SMK KESEHATAN BALI MEDIKA DENPASAR}

\section{ABSTRACT}

Hand grip strength is one of the essential elements of conducting the activity. The purpose of this research is to know the relationship between body fat percentage and BMI with hand grip strength in teenage girls aged 15-17 years at SMK Kesehatan Bali Medika Denpasar. This research is a cross sectional analytic research conducted in April 2019. Samples were taken with Simple Random Sampling technique with sample of 85 people. The hypothesis test used was Chi Square Test and obtained the result of $P 0.002$ for hand grip strength relationship with body fat percentage, and $P$ 0.024 for the relationship with $\mathrm{BMI}$, or $\mathrm{P}<0.05$. The youth Prevalence Ratio has a weak hand grip strength category is $4.073[95 \% \mathrm{Cl} 1.629-10.186]$ for the category of overweight fat percentage and obesity compared to good and acceptable categories as well as 2.771 [95\% $\mathrm{Cl} 1.128-6.808$ ] for comparison BMI category obesity and overweight with the normal category. Based on the results of the study, there is a correlation between the percentage of body fat with hand grip strength, and the correlation between BMI with hand grip strength in teenage girls aged 15-17 years at SMK Kesehatan Bali Medika Denpasar. Categories Overweight and obesity have a risk of 4.073 times higher in the weak hand grip category compared to the category of good and acceptable fat percentages, and the category of obese and overweight 2.771 Times higher than a person in the normal BMI category.

Keywords: body fat percentage, BMI, hand grip strength

\section{PENDAHULUAN}

Pada dewasa ini kemajuan teknologi telah memberikan banyak kemudahan dan berbagai cara baru untuk manusia dalam melakukan aktivitas. ${ }^{1}$ Berbagai jenis kegiatan yang sebelumnya menuntut kemampuan fisik yang cukup besar sekarang cenderung telah digantikan oleh mesin-mesin otomatis. ${ }^{2}$ Perilaku kurangnya aktivitas fisik inilah dapat berimbas pada pengurangan massa otot dan peningkatan adipositas apalagi apabila diimbangi dengan asupan makanan berlebih. ${ }^{3}$ Menurut penelitian, remaja yang melakukan perilaku sedentari lebih lama ( $>5$ jam/hari) berisiko 2,9 kali lebih besar untuk mengalami obesitas atau penimbunan lemak berlebih. Terutama remaja pada daerah urban yang waktu sedentarinya lebih dipengarui oleh waktu berkendara, les, dan penggunaan alat elektronik seperti handphone dan laptop. ${ }^{4}$ Penelitian lain mengenai remaja juga menyatakan remaja yang berumur $15-17$ tahun hampir seluruhnya sering mengkonsumsi fast food. ${ }^{5}$ Kebiasaan hal ini tentu akan memberi efek negatif bagi tubuh terutama pada sistem muskuloskeletal. 
Menurut data angka prevalensi obesitas berdasarkan status gizinya di Indonesia pada remaja usia 16-18 tahun meningkat $1,4 \%$ menjadi $7,3 \%$ pada 2013 , namun di sisi lain angka juga menunjukan peningkatan prevalensi sangat kurus sebanyak 0,4\%. Hal serupa juga tercatat pada remaja usia 13-15 tahun, dimana prevalensi kurus mencapai $11,1 \%$ sedangkan dengan kategori gemuk sejumlah 10,8\%. Ini berarti Indonesia tidak hanya menghadapi permasalahan kelebihan gizi namun juga kekuarangan gizi pada remaja. ${ }^{6}$

Masalah status gizi yang digambarkan melalui IMT yang terjadi di Indonesia ini tentu akan berimbas pada berbagai hal, salah satunya adalah fungsi otot yang terganggu pada remaja dengan status gizi rendah. Status gizi berkaitan dengan kekuatan otot genggam dikaitkan dengan status gizi yang akan berperan dalam pembentukan massa tubuh. ${ }^{7}$ Namun tingginya IMT dapat pula diasumsikan dengan tingginya lemak tubuh. Tingginya persentase lemak dapat menurunkan kekuatan otot, karena perbedaan tingkat aktivitas fisik seseorang dengan kategori persentase lemak tubuh yang berbeda. ${ }^{8}$

Kelemahan otot tentunya akan menghambat dalam melakukan aktivitas fungsional, khususnya remaja yang memiliki berbagai macam aktivitas, Tidak hanya kemampuan fungsional, kekuatan otot juga dijadikan prediktor untuk berbagai kondisi. Lemahnya kekuatan otot genggam yang dianggap mewakili kekuatan otot seluruh tubuh, menurut penelitian berkaitan kuat dengan risiko metabolic syndrome. Penelitian yang dilakukan di Korea ini menyatakan bahwa semakin tinggi relative hand grip strength maka semakin rendah risiko seseorang mengalami metabolic syndrome dibandingkan dengan yang memilki relative hand grip strength lebih lemah. ${ }^{9}$ Selain itu, lemahnya kekuatan otot genggam telah dinyatakan berhubungan dengan rendahnya kemampuan fungsional pada lansia. ${ }^{10}$

Maka dari itu peneliti menganggap penting untuk mengetahui faktor-faktor apa saja yang mempengaruhi kekuatan otot melalui pengukuran kekuatan otot genggam untuk menggambarkan kekuatan otot secara keseluruhan, terutama terkait dengan persentase lemak tubuh dan IMT yang menggambarkan status gizi pada remaja putri, dikarenakan perempuan memiliki kecenderungan penumpukan deposit lemak yang lebih tinggi dari pada laki- laki, selain itu data menunjukan pada pria kekuatan otot genggam hanya turun sebesar $20 \%$ sedangkan wanita mencapai $30 \%$ karena perbedaan aktivitas tiap gendernya. ${ }^{11}$

\section{METODE}

Penelitian ini merupakan penelitian cross sectional analytic yang menggunakan 85 orang sampel remaja putri berusia 15-17 tahun di SMK Kesehatan Bali Medika Denpasar. Penelitian ini dilaksanakan pada 11 dan 14 April 2019. Sampel dipilih melalui teknik simple random sampling yang sebelumnya telah memenuhi kriteria inklusi diantaranya, merupakan siswi SMK usia 15-17 tahun, bersedia secara sukarela mengikuti tahapan penelitian sebagai sampel atas persetujuan orang tua/wali subjek dengan menandatangani informed consent, menggunakan tangan kanan sebagai tangan dominan dan tidak memenuhi kriteria eksklusi berupa sedang menderita inflamasi dan atau deformitas pada tangan yang menghambat gerakan dan kekuatan tangan, atlet dan atau sedang mengikuti program gym, merokok dan rutin mengonsumsi alkohol, memiliki IMT kategori sangat kurus dan kurus, memiliki persentase lemak kategori atletic.

Variabel independen pada penelitian ini adalah IMT dan persentase lemak, variabel dependen adalah kekuatan otot genggam sedangkan aktivitas fisik dianalisis sebagai variabel kontrol. Persentase lemak tubuh diukur dengan BIA merek Omron yang dikategorikan menjadi kategori atletic (10-15\%), good (16-19\%), acceptable (20-25\%), overweight $(26-29 \%)$, obesitas $(\geq 30 \%)$. IMT diukur dengan membagi antara berat badan dalam satuan kg sampel dengan tinggi badan kuadrat dalam satuan meter yang telah diukur sebelumnya yang kemuadian dikategorikan menurut nilai $Z$ - score menjadi kategori sangat kurus, kurus, normal, gemuk, obesitas menurut Kementrian Kesehatan. Kekuatan otot genggam dinilai melalui pengukuran dengan alat hand grip dynamometer yang hasilnya dikategorikan menjadi weak ( $<15,5 \mathrm{~kg}$ untuk kategori umur 14-15 tahun dan $<17,2 \mathrm{~kg}$ untuk kategori umur 16-17 tahun), normal (15,5-27,3 kg untuk kategori umur 14-15 tahun dan 17,2-29,0 kg untuk kategori umur 16-17 tahun), strong (>27,3 kg untuk kategori umur 14-15 tahun dan $>29 \mathrm{~kg}$ untuk kategori umur 16-17 tahun) sesuai dengan jenis kelamin perempuan. Aktivitas fisik didata dengan pengisian kuisioner IPAQ-SF.

Data yang terkumpul lalu diuji dengan Chi Square Test untuk mengetahui hubungan persentase lemak dengan kekuatan otot genggam, dan hubungan IMT dengan kekuatan otot genggam. Data variabel independen juga diuji dan dibandingkan prevalence rationya terhadap kemungkinan responden memiliki kategori otot lemah.

\section{HASIL}

Penelitian ini mendata 85 orang siswi dari kelas X hingga XII dengan rentang usia 15-17 tahun. Berikut adalah tabel analisis data penelitian.

Tabel 1. Distribusi Frekuensi Karakteristik Responden

\begin{tabular}{lcc}
\hline \multicolumn{1}{c}{ Variabel } & Frekuensi (n) & Presentase (\%) \\
\hline IMT & 51 & 60 \\
$\quad$ Normal & 24 & 28,2 \\
Gemuk & 10 & 11,8 \\
$\quad$ Obesitas & & \\
Persentase Lemak & 14 & 16,5 \\
$\quad$ Good & 32 & 37,6 \\
$\quad$ Acceptable & 22 & 25,9 \\
$\quad$ Overweight & 17 & 20 \\
$\quad$ Obesitas & & \\
Kekuatan Otot Genggam & 33 & 38,8 \\
$\quad$ Weak & &
\end{tabular}




\begin{tabular}{ccc} 
Normal & 40 & 47,1 \\
Strong & 12 & 14,1 \\
Aktivitas Fisik & & \\
Rendah & 38 & 44,7 \\
Sedang & 39 & 45,9 \\
Tinggi & 8 & 9,4 \\
\hline
\end{tabular}

Berdasarkan Tabel 1 dapat dilihat bahwa responden mayoritas memiliki kategori IMT normal yaitu sebesar $60 \%$, dan kategori persentase lemak terbanyak ada pada kategori acceptable sebesar 37,6\%. Dilihat dari kategori kekuatan otot genggam, responden terdata $47,1 \%$ memiliki kategori normal. Kategori aktivitas fisik tertinggi ada pada kategori sedang yaitu sebesar $45,9 \%$.

Tabel 2. Hubungan Persentase Lemak Tubuh dengan Kekuatan Otot Genggam

\begin{tabular}{ccccc}
\hline \multirow{2}{*}{ Persentase Lemak } & \multicolumn{2}{c}{ Kekuatan Otot Genggam } & \multirow{2}{*}{ Total } & \multirow{2}{*}{ p } \\
\cline { 2 - 4 } & Weak & Normal dan Strong & & \\
\hline Good dan Acceptable & $12(26,10 \%)$ & $34(73,90 \%)$ & $45(100 \%)$ & \multirow{2}{*}{0,002} \\
Overweight dan Obesitas & $23(59,00 \%)$ & $16(41,00 \%)$ & $39(100 \%)$ & \\
\hline
\end{tabular}

Tabel 2 menunjukan uji Chi Square Test pada hubungan persentase lemak dengan kekuatan otot genggam, yang mendapatkan nilai $p$ sebesar 0,002 sehingga nilai $p<0,05$. Berdasarkan uji statistik dapat ditemukan bahwa ada hubungan yang signifikan antara persentase lemak tubuh terhadap kekuatan otot genggam pada siswi SMK Kesehatan Bali Medika Denpasar.

Tabel 3. Prevalence Ratio Persentase Lemak Tubuh

Terhadap Risiko Seseorang Memiliki Kategori Otot Genggam Lemah Prevalence Ratio untuk Persentase Lemak Tubuh (Obese-Overweight/Good-Acceptable)

\begin{tabular}{ccc} 
& \multicolumn{2}{c}{$95 \%$ Confidence Interval } \\
\cline { 2 - 3 } Value & Lower & Upper \\
\hline 4,073 & 1,629 & 10,186 \\
\hline
\end{tabular}

Perbandingan risiko responden memiliki kategori otot genggam lemah antara responden dengan persentase lemak kategori good dan acceptable dan kategori overweight dan obesitas.dapat dilihat pada Tabel 3. Nilai prevalence ratio untuk kategori overweight dan obesitas dibandingkan dengan kategori good dan acceptable ialah 4,073 [95\% Cl $1,629-10,186$ ] yang berarti seseorang dengan kategori overweight dan obesitas memiliki risiko 4,073 atau 4 kali lebih tinggi berisiko memilki kategori otot genggam lemah dibandingkan seseorang dengan kategori persentase lemak good dan acceptable. Selain itu dalam rentangan confidence interval tidak mengandung nilai 1 sehingga menunjukan risiko memiliki kategori otot genggam lemah pada kategori persentase lemak overweight dan obesitas daripada good dan acceptable signifikan pada taraf signifikansi $5 \%$.

Tabel 4. Hubungan IMT dengan Kekutan otot Genggam

\begin{tabular}{|c|c|c|c|c|}
\hline \multirow{2}{*}{ IMT } & \multicolumn{2}{|c|}{ Kekuatan Otot Gemggam } & \multirow{2}{*}{ Total } & \multirow{2}{*}{$p$} \\
\hline & Weak & Normal- Strong & & \\
\hline $\begin{array}{l}\text { Normal } \\
\text { Gemuk dan Obesitas }\end{array}$ & $\begin{array}{l}16(31,40 \%) \\
19(55,90 \%)\end{array}$ & $\begin{array}{l}35(68,6 \%) \\
15(44,1 \%)\end{array}$ & $\begin{array}{l}51(100 \%) \\
34(100 \%)\end{array}$ & 0,024 \\
\hline
\end{tabular}

Hasil penelitian setelah dilakukan uji Chi Square Test yang dijabarkan pada Tabel 4 mendapatkan nilai p sebesar 0,024 sehingga nilai $p<0,05$. Berdasarkan uji statistik dapat ditemukan bahwa ada hubungan yang signifikan antara IMT terhadap kekuatan otot genggam pada siswi SMK Kesehatan Bali Medika Denpasar.

Tabel 5. Prevalence Ratio IMT Terhadap Risiko Seseorang Memiliki Kategori Otot Genggam Lemah 95\% Confidence Interval

\begin{tabular}{cccc}
\hline Prevalence Ratio untuk IMT & Value & Lower & Upper \\
\hline ( Normal/Obesitas dan Gemuk) & 2,771 & 1,128 & 6,808 \\
\hline
\end{tabular}

Tabel 5 menejelaskan Nilai prevalence ratio untuk kategori obesitas dan gemuk dibandingkan dengan kategori normal ialah 2,771 [95\% Cl 1,128-6,808] yang berarti seseorang dengan kategori IMT gemuk dan obesitas memiliki risiko berkategori otot genggam lemah (weak) 2,771 atau 2,8 kali lebih tinggi dibandingkan dengan seseorang dengan kategori IMT normal. Selain itu dalam rentangan confidence interval tiak mengandung nilai 1 sehingga menunjukan risiko seseorang memiliki kategori otot genggam lemah pada seseorang dengan kategori obesitas dan gemuk daripada IMT normal signifikan pada taraf signifikansi $5 \%$.

Tabel 6. Distribusi Kekuatan Otot Genggam Berdasarkan Aktivitas Fisik dan Persentase Lemak

\begin{tabular}{|c|c|c|c|c|}
\hline \multirow{2}{*}{\multicolumn{2}{|c|}{ Persentase Lemak }} & \multicolumn{2}{|c|}{ Kekuatan Otot Genggam } & \multirow[b]{2}{*}{ Total } \\
\hline & & Weak & Normal dan Strong & \\
\hline \multirow{3}{*}{ Good dan Acceptable } & Rendah & $8(57,10 \%)$ & $6(42,90 \%)$ & 14 \\
\hline & Aktivitas Fisik Sedang dan Tingg & $4(12,50 \%)$ & $28(87,50 \%)$ & $32(100 \%)$ \\
\hline & Total & $12(26,10 \%)$ & $34(73,90 \%)$ & $46(100 \%)$ \\
\hline & Rendah & $18(75,00 \%)$ & $6(25,00 \%)$ & $24(100 \%)$ \\
\hline \multicolumn{2}{|c|}{ Overweigth dan Obesitas Aktivitas Fisik Sedang dan Tinggi } & $5(33,30 \%)$ & $10(66,70 \%)$ & $15(100 \%)$ \\
\hline & Total & $23(59,00 \%)$ & $16(41,00 \%)$ & $39(100 \%)$ \\
\hline
\end{tabular}


Berdasarkan Tabel 6 diketahui bahwa seseorang dengan kategori persentase lemak yang sama dapat memiliki kategori kekuatan otot yang berbeda apabila dikaitkan kembali dengan aktivitas fisiknya. Diketahui mayoritas dari responden berkategori good dan acceptable dengan aktivitas fisik rendah cenderung memiliki kekuatan otot kategori weak (57,1\%) sedangkan yang memiliki aktivitas fisik sedang dan tinggi sebanyak 87,5\% memiliki kategori normal dan strong. Begitu pula pada responden dengan kategori obesitas dan overweight dengan aktivitas fisik rendah cenderung memiliki kateori otot weak (75\%), dan responden dengan aktivitas fisik sedang dan tinggi didominasi responden berkategori normal dan strong yaitu sebesar $66,7 \%$.

Tabel 7. Distribusi Kekuatan Otot Genggam Berdasarkan Aktivitas Fisik dan IMT

\begin{tabular}{|c|c|c|c|c|c|}
\hline \multirow{2}{*}{\multicolumn{3}{|c|}{ IMT }} & \multicolumn{2}{|c|}{ Kekuatan Otot Genggam } & \multirow{2}{*}{ Total } \\
\hline & & & Weak & Normal dan Strong & \\
\hline \multirow{4}{*}{ Normal } & \multirow{4}{*}{ Aktivitas Fisik } & Rendah & $11(61,10 \%)$ & $7(38,90 \%)$ & $18(100 \%)$ \\
\hline & & Sedang dan Tinggi & $5(15,20 \%)$ & $28(84,80 \%)$ & 33 \\
\hline & & Total & $16(31,40 \%)$ & $35(68,60 \%)$ & 51 \\
\hline & & Rendah & $15(75,0 \%)$ & $5(25,00 \%)$ & 20 (100\%) \\
\hline \multirow[t]{2}{*}{ Gemuk dan Obesitas } & \multirow[t]{2}{*}{ Aktivitas Fisik } & Sedang dan Tinggi & $4(28,60 \%)$ & $10(71,40 \%)$ & $14(100 \%)$ \\
\hline & & Total & $19(55,90 \%)$ & $15(44,10 \%)$ & $34(100 \%)$ \\
\hline
\end{tabular}

Dari Tabel 7 dapat dilihat bahwa terdapat perbedaan kategori kekuatan otot genggam responden yang memiliki IMT yang sama, namun dengan aktivitas fisik yang berbeda. Responden dengan IMT normal namun aktivitas fisik rendah cenderung memiliki kekuatan otot genggam weak yaitu sebesar $61,1 \%$, sedangkan dengan yang memiliki aktivitas fisik tinggi dan sedang mayoritas memiliki kategori normal dan strong yaitu 84,8\%. Responden dengan IMT gemuk dan obesitas dengan aktivitas fisik rendah sebanyak 75\% memiliki kekuatan otot gengggam weak, sedangkan yang memiliki aktivitas fisik sedang dan tinggi cenderung memiliki kekuatan kategori normal dan strong sebanyak $71,4 \%$.

\section{DISKUSI \\ Karakteristik Responden}

Responden yang dipilih merupakan remaja putri berusia 15-17. Sebagian besar responden memiliki aktivitas fisik tingkat rendah sebesar 38 orang $(44,7 \%)$, 39 orang (45,9\%) sedang, dan kategori tinggi 8 orang (9,4\%). Ini serupa dengan hasil RISKESDAS yang mencatat bahwa penduduk dengan jenis kelamin wanita dan tinggal di daerah perkotaan lebih banyak memiliki perilaku sedentari $\geq 6$ jam. ${ }^{6}$

Dilihat dari distribusi komposisi tubuh responden, terdata bahwa sebagian besar responden memiliki IMT normal yaitu sebesar $60 \%$, disusul dengan IMT gemuk $28,2 \%$, dan kategori dengan jumlah terendah yaitu IMT obesitas sebesar $11,8 \%$. Tingginya presentase kategori gemuk dan obesitas dapat dikarenakan rendahnya aktivitas fisik responden yang didukung dari data sebaran aktivitas fisik pada penelitian ini, dimana aktivitas fisik dapat mempengaruhi IMT. ${ }^{12}$

Ditinjau dari persentase lemak responden yang dikategorikan menjadi Good, Acceptable, Overweight, Obesitas, diketahui sebanyak 14 orang (16,5\%) memiliki persen lemak kategori good 32 orang (37,6\%) kategori acceptable, 22 orang $(25,9 \%)$ kategori overweight, dan 17 orang $(20,0 \%)$ kategori obesitas. Temuan dominasi kategori good dan acceptable sebesar $54,1 \%$ ini cenderung linier dengan temuan kategori IMT yang didominasi dengan kategori normal. Ini sesuai dengan teori bahwa ada hubungan linier antara IMT dengan persentase lemak. ${ }^{13}$

Dan dari total 85 responden sebanyak 38,8\% tergolong weak atau lemah, sedangkan $47,1 \%$ normal dan $14,1 \%$ strong atau kuat. Ini serupa dengan temuan penelitian sebelumnya yang mencatat kekuatan otot genggam kategori kuat/ baik hanya sebesar $3 \%$ atau terendah dari keseluruhan kategori responden. ${ }^{14}$

\section{Hubungan Persentase Lemak Tubuh dengan Kekuatan Otot Genggam}

Berdasarkan hasil pengujian data dengan Chi Square Test pada jumlah data penelitian sebanyak 85 responden, ditemukan nilai $p$ yaitu sebesar 0,002 pada hasil analisis hubungan persentase lemak tubuh dengan kekuatan otot sehingga nilai $p<0,05$, sehingga dapat disimpulkan bahwa ada hubungan antara persen lemak dengan kekuatan otot genggam pada remaja putri usia 15-17 tahun di SMK Kesehatan Bali Medika Denpasar. Selain itu penelitian ini mendapatkan hasil signifikan pada prevalence ratio untuk kategori kategori overweight dan obesitas dibandingkan dengan kategori good dan acceptable ialah 4,073 [95\% Cl 1,629-10,186] yang berarti seseorang dengan kategori overweight dan obesitas memiliki risiko 4,073 atau 4 kali lebih tinggi memiliki kategori otot lemah ( weak) dibandingkan seseorang dengan kategori persentase lemak good dan acceptable. Diketahui pula mayoritas dari responden berkagori good dan acceptable dengan aktivitas fisik rendah cenderung memiliki kekuatan otot kategori weak (57,1\%) sedangkan yang memiliki aktivitas fisik sedang dan tinggi sebanyak 87,5\% memiliki kategori normal dan strong. Begitu pula pada responden dengan kategori obesitas dan overweight dengan aktivitas fisik rendah cenderung memiliki kateori otot weak (75\%), dan responden dengan aktivitas fisik sedang dan tinggi didominasi responden berkategori normal dan strong yaitu sebesar $66,7 \%$.

Hasil ini serupa dengan penelitian Sartorio yang juga meneliti kekuatan otot genggam pada remaja usia 5 - 15 tahun terhadap persentase lemak tubuh, yang menunjukan adanya hubungan negatif diantara keduanya. ${ }^{15}$ Persentase lemakpun memiliki korelasi dengan kekuatan otot, menurut penelitian yang dilakukan Setiowati dengan menggunakan BIA terhadap kekuatan otot total tubuh menunjukan hubungan negatif diantaranya, walau dengan teknik pengukuran kekuatan otot yang berbeda namun penelitian ini juga memperjelas hubungan lemak terhadap fungsi otot. ${ }^{16}$

Dibandingkan dengan remaja dengan persentase lemak normal, remaja obese mengalami penurunan pola rekruitmen serabut otot dan mobilitas. Orang dengan kondisi obesitas juga merupakan orang yang cenderung memiliki aktivitas fisik yang kurang sehingga ini akan mempengaruhi kualitas otot. Data mencatat, wanita obese memiliki 
kekuatan yang lebih rendah pada ekstremitas atas dan bawah dibandingkan dengan wanita kurus, yang bisa dikarenakan rendahnya derajat aktvitas mereka. ${ }^{8} \mathrm{Hal}$ ini sesuai dengan sebaran data aktivitas fisik penelitian ini, dimana sesorang dengan kategori persentase lemak yang sama dapat memiliki kategori kekuatan otot yang berbeda apabila dikaitkan kembali dengan aktivitas fisiknya. Sehingga dapat diamati kondisi persentase lemak berlebih cenderung berdampingan dengan rendahnya aktivitas fisik yang berimbas pada kekuatan otot. Selain itu obesitas dan rendahnya aktivitas fisik juga berisiko terhadap potensi peningkatan intramuscular fat yang berpengaruh pada kualitas otot. ${ }^{17}$

\section{Hubungan IMT dengan Kekuatan Otot Genggam}

Berdasarkan hasil pengujian data dengan Chi Square Test pada jumlah data penelitian sebanyak 85 responden, ditemukan nilai $p$ yaitu sebesar 0,024 pada hasil analisis hubungan IMT dengan kekuatan otot sehingga nilai $p<0,05$. Sebagaimana dasar pengambilan keputusan yang telah ditetapkan maka dalam penelitian ini berarti Ho ditolak dan Ha diterima, sehingga dapat disimpulkan bahwa ada hubungan antara IMT dengan kekuatan otot genggam pada remaja putri usia 15-17 tahun di SMK Kesehatan Bali Medika Denpasar. Selain itu didapatkan hasil signifikan pada prevalence ratio untuk kategori obesitas- gemuk dibandingkan dengan kategori normal ialah 2,771 [95\% Cl 1,128-6,808] yang berarti seseorang dengan kategori IMT gemuk dan obesitas memiliki risiko memiliki kategori kekuatan otot genggam lemah (weak) 2,771 atau 2,8 kali lebih tinggi dibandingkan dengan seseorang dengan kategori IMT normal. Pada penelitian ini dapat dilihat Responden dengan IMT normal namun aktivitas fisik rendah cenderung memiliki kekuatan otot genggam weak yaitu sebesar $61,1 \%$, sedangkan dengan yang memiliki aktivitas fisik tinggi dan sedang mayoritas memiliki kategori normal dan strong yaitu 84,8\%. Responden dengan IMT gemuk dan obesitas dengan aktivitas fisik rendah sebanyak $75 \%$ memiliki kekuatan otot gengggam weak, sedangkan yang memiliki aktivitas fisik sedang dan tinggi cenderung memiliki kekuatan kategori normal dan strong.

Salah satu penelitian telah menjelaskan terdapat hubungan negatif antara indeks massa tubuh dengan kekuatan otot genggam walaupun dengan perbedaan usia sample. ${ }^{18}$ Namun temuan ini didukung oleh hasil penelitian lain pada tahun 2017 yang menyatakan, walaupun lemah terdapat hubungan negatif antara IMT dengan kekuatan otot genggam pada wanita overweight dan hubungan yang negatif signifikan pula pada laki- laki dengan IMT normal maupun obese. ${ }^{19}$

IMT yang menggambarkan status gizi yang akan berperan dalam pembentukan massa tubuh. ${ }^{7}$ Semakin tinggi berat badan seseorang maka akan berimbas pada tingginya IMT. ${ }^{20}$ Namun disisi lain terlalu tingginya IMT pada remaja juga dapat dikarenakan oleh tingginya lemak, ini dikarenakan ketika mengukur IMT seseorang, tidak dapat dibedakan antara massa otot atau lemak yang dominan terukur, sehingga lemahnya kekuatan otot genggam pada subjek diteliti dapat terjadi dengan alasan tingginya lemak pada tubuh subjek daripada massa otot pada subjek gemuk dan obese, hal ini didukung oleh Romero Coral et al yang menyatakan hubungan IMT dan persen lemak lebih tinggi pada remaja daripada orang tua. ${ }^{21}$ Penelitian lain menyatakan hal serupa yaitu pada anak muda , IMTnya dianggap lebih berkorelasi dengan lemak daripada massa otot. ${ }^{13}$ Pada penelitian ini diteliti hubungan IMT berlebih dengan kejadian kelemahan kelemahan otot genggam yang menghasilkan hasil signifikan pada uji hipotesis sehingga dapat disimpulkan IMT berlebih dapat menurunkan kekuatan otot genggam apabila dikaitkan dengan tingginya lemak pada remaja IMT berlebih dan rendahnya aktivitas fisik yang menyertai tingginya persentase lemak tersebut. Serupa dengan persentase lemak, hubungan IMT ini dengan kekuatan otot genggam terkait dengan aktivitas fisik masing- masing responden yang pada penelitian ini terlihat kecenderungan rendahnya aktivitas fisik dengan tingginya IMT berimbas pada rendahnya kekuatan otot genggam responden. Ini menunjukan komposisi tubuh yang baik apabila diikuti dengan aktivitas fisik yang tinggi atau sedang baru akan menghasilkan kekuatan otot yang baik pula, sehingga ini menegaskan keterkaitan aktivitas fisik dan komposisi tubuh dalam hal ini IMT dalam membentuk kekuatan otot.

\section{SIMPULAN}

Terdapat hubungan antara persentase lemak tubuh dan kekuatan otot genggam pada remaja putri usia 15-17 tahun di SMK Kesehatan Bali Medika Denpasar. Seseorang dengan kategori overweight dan obesitas memiliki risiko 4,073 atau 4 kali lebih tinggi memiliki kategori otot genggam lemah (weak) dibandingkan seseorang dengan kategori persentase lemak good dan acceptable, dengan nilai prevalence ratio 4,073 [95\% Cl 1,629-10,186].

Serta terdapat hubungan antara IMT dengan kekuatan otot genggam pada remaja putri usia 15-17 tahun di SMK Kesehatan Bali Medika Denpasar. Seseorang dengan kategori IMT gemuk dan obesitas memiliki risiko memiliki kategori kekuatan otot genggam lemah 2,771 atau 2,8 kali lebih tinggi dibandingkan dengan seseorang dengan kategori IMT normal, dengan nilai prevalence ratio 2,771 [95\% Cl 1,128-6,808].

\section{DAFTAR PUSTAKA}

1. Ngafifi, M. Advances in Technology and Patterns of Human Life in Socio-Cultural Perspective, Kemajuan Teknologi dan Pola Hidup Manusia. Jurnal Pembangunan Pendidikan: Fondasi dan Aplikasi; 2014; 2(1): 33-47.

2. Dwiningrum, S.I.A. IImu Sosial \& Budaya Dasar. Yogyakarta: UNY Press. 2012. h. 171.

3. Guyton, A.C, and Hall, J.E. Buku Ajar Fisiologi Kedokteran 2012 (11). Jakarta: EGC. 2008. h. 917.

4. Mandriyarini, R., Sulchan, M. and Nissa, C. Sedentary Lifestyle sebagai Risiko Kejadian Obesitas pada Remaja SMA Stunted di Kota Semarang. Journal of Nutrition College; 2017.

5. Mahpolah, Mahdalena and Purnamasari, V. Faktor-faktor yang Berhubungan dengan Kebiasaan Mengkonsumsi Fast Food pada Remaja SMA Kartika V-1. Jurnal Kedokteran Yarsi; 2008; 16(3): 1-12.

6. Riset Kesehatan Dasar Kementerian Kesehatan Republik Indonesia. Kemenkes; 2013: 1-384.

7. Manoharan, V.S., Sundaram, S.G. and Jason, J.I. Factors Affecting Hand Grip Strength and Its Evaluation: a Systemic Review. International Journal of Physiotherapy and Research; 2015; 3(6): 1288-1293.

8. Norman, K., Stobäus, N., Gonzalez, M., C,Schulzke, J.D., Pirlich, M. Hand Grip Strength: Outcome Predictor and Marker of Nutritional Status', Clinical Nutrition. Elsevier Ltd; 2011; 30(2): 135-142. 
9. Yi, D. Khang, A.R., Lee, H.W., Son, S.M., Kang, Y.H. Relative Handgrip Strength as a Marker of Metabolic syndrome: the Korea National Health and Nutrition Examination Survey (KNHANES) VI (2014-2015), Diabetes, metabolic syndrome and obesity : targets and therapy; 2018; 11: 227-240.

10. Putri, D., Purnawati, S. Hubungan Kekuatan Otot Genggam dan Kemampuan Fungsional pada Lansia Wanita di Posyandu Lansia Desa Dauh Puri Kelod Denpasar Barat. E-Jurnal Medika; 2017; 6(4): 20-27.

11. Aszahro, S.F. Status Daya Tahan Umum Kekuatan Otot Tungkai dan Kecepatan Pemain Futsal Putri SMA Negeri 1 Sewon dan SMK Negeri 3 Yogyakarta. Prodi Pendidikan Jasmani Kesehatan dan Rekreasi Jurusan Pendidikan Olahraga Fakultas IImu Keolahragaan Universitas Negeri Yogyakarta; 2017: 26.

12. Guiné, R.P.F., Fernandes, S.R., Abrantes, J.L., Cardoso, A.P., Ferreira, M. Factors Affecting the Body Mass Index in Adolescents in Portuguese Schools, Croatian Journal of Food Technology. Biotechnology and Nutrition; 2016; 11(1-2): 58-64.

13. Kanehisa, H. and Fukunaga, T. Association Between Body Mass Index and Muscularity in Healthy Older Japanese Women and Men. Journal of Physiological Anthropology; 2013; 2(1): 1.

14. Ryoto, V. Hubungan Antara Kekuatan Otot Genggam dengan Umur, Tingkat Kemandirian, dan Aktivitas Fisik pada Lansia Wanita Klub Geriati Terpilih Jakarta Utara tahun 2012, Skripsi Progam Studi IImu Gizi Universitas Indonesia; 2012: 66-67.

15. Sartorio, A., Lafortuna, C.L., Pogliaghi, S., Trecate, L., The Impact of Gender, Body Dimension and Body Composition on Hand Grip Strength in Healthy Children. J Endocrinol.Invest; 2002; 25: 431-435.

16. Setiowati, A. Hubungan Indeks Massa Tubuh, Persentase lemak tubuh, Asupan Zat Gizi dengan Kekuatan Otot. Jurnal Media IImu Keolahragaan Indonesia; 2014; 4(1): 32-38.

17. Tomlinson, D.J., Erskine, R.M., Morse, C.I., Winwood, K., Onambélé-Pearson, G. The Impact of Obesity on Skeletal Muscle Strength and Structure Through Adolescence to Old Age. Biogerontology; 2016; 17(3): 467-483.

18. Bassi, R., Sharma, S., Kaur, S., Sharma, A., Handgrip dynamometry in Elderly Individual and Its Relation With Body Mass Index. National Journal of Physiology, Pharmacy and Pharmacology; 2016; 6(1).

19. Dhananjaya J.R., Veena H.C., Mamatha B.S., Sudharsan C.R. Comparative Study of Body Mass Index, Hand Grip Strength, and Handgrip Endurance in Healthy Individuals. Natl J Physiol Pharm Pharmacol; 2017; 7(6): 594-598.

20. Adi Putri, N.M.R., Wibawa, A., Sugiritama, I.W., Muliarta, I.M. Wanita Overweight dan Obesitas Memiliki Sudut Eversi Calcaneus Lebih Besar dan Ekstensibilitas Gastrocnemius Lebih Kecil Daripada Wanita Normal di Desa Mangesta, Kecamatan Penebel, Kabupaten Tabanan. Majalah IImiah Fisioterapi Indonesia; 2016; 4(1).

21. Romero-Corral, A., Somers V.K., Sierra-Johnson J., Thomas, R.J., Collazo-Clavell, M.L., Korinek, J., Allison, T.G., Batsis, J.A., Sert-Kuniyoshi F.H., Lopez J.F. Accuracy of Body Mass Index to Diagnose Obesity in the US Adult Population. Int J Obese; 2008; 32(6). 